\title{
Innovative combined in-cycle trigeneration technologies for food industries
}

\author{
Andrii Radchenko ${ }^{1}$, Dariusz Mikielewicz ${ }^{2}$, Mykola Radchenko ${ }^{1 *}$, Serhiy Forduy ${ }^{1}$, Oleksandr Rizun ${ }^{1}$ and Viktor \\ Khaldobin $^{1}$ \\ ${ }^{1}$ Admiral Makarov National University of Shipbuilding, 9 Heroes of Ukraine Avenue, Mykolayiv, Ukraine \\ ${ }^{2}$ Gdańsk University of Technology, 11/12 Gabriela Narutowicza Street, 80-233 Gdansk, Poland
}

\begin{abstract}
The majority of integrated energy systems (IES) for combined electricity, heat and refrigeration generation, or trigeneration, are based on gas engines. The fuel efficiency of gas engines are strictly influenced by intake air temperatures. Practically in all IES the absorption lithium-bromide chillers (ACh) are applied for conversing the heat removed from the engine into refrigeration in the form of chilled water. The peculiarity of trigeneration in food industries is the use of chilled water of about $12^{\circ} \mathrm{C}$ for technological needs instead of $7^{\circ} \mathrm{C}$ as typical for ACh. This leads to a considerable great potential of engine intake air deeper cooling not realized by $\mathrm{ACh}$, that can be used by ejector chiller (ECh) as the low temperature stage of two-stage absorption-ejector chiller (AECh) to provide engine cyclic air deep cooling and enhancing engine fuel efficiency. To evaluate the effect of gas engine cyclic air cooling the data on fuel consumption and power output of gas engine JMS 420 GS-N.L were analyzed.
\end{abstract}

\section{Introduction}

The gas engines (GE) [1, 2] found a widespread application in integrated energy systems (IES), trigeneration or systems for combined cooling, heat and power (electricity) generation (CCHP) [3, 4]. With a rise in intake air temperature a thermodynamic efficiency of GE essentially decreases: electric power output decreases and specific fuel consumption increases. A refrigeration capacity, generated by absorption lithiumbromide chiller $(\mathrm{ACh})$, that recovers the heat released from the engine, can be used (in addition to technological or other needs) for engine intake air cooling (EIAC) as in-cycle trigeneration [5, 6]. This provides not only improvement of engine fuel efficiency, but also prolong the time of efficient operation of trigeneration plant [7, 8], since cooling demands for technological needs have, as a rule, periodic character.

The peculiarity of trigeneration in food industries is the use of chilled water of about $12^{\circ} \mathrm{C}$ for technological needs instead of $7^{\circ} \mathrm{C}$ as typical for ACh. This leads to a considerable great potential of engine intake air deeper cooling not realized by $\mathrm{ACh}$, that can be used by ejector chiller (ECh) as the low temperature stage of two-stage absorption-ejector chiller (AECh) to provide engine cyclic air deep cooling and enhancing engine fuel efficiency $[9,10]$.

A conventional method of chilling all the ambient air, coming into the engine room, from were it is sucked by engine turbocharger (TC), is non-effective because of heat influx from surroundings to the air stream sucked, that results in increased air temperature at the inlet of turbocharger and enlarged cooling capacity required [11].

\section{Literature review}

Many researches deal with improving the performance efficiency of trigeneration plants based on combustion engines for space conditioning $[12,13]$, technological and other needs. A lot of publications are devoted to enhancing the fuel efficiency of engines by cooling cyclic air with application of waste heat recovery chillers [14-16]. The absorption lithium-bromide chillers (ACh) are the most widely used and provide cooling air to about $15^{\circ} \mathrm{C}$ with a high coefficient of performance (COP $=0.7-0.8)[17,18]$. The jet devices as thermopressors [19-21] and ejector chillers (ECh) $[22,23]$ are the most simple. The ECh enable to provide cooling air to $10^{\circ} \mathrm{C}$ and lower but with a low COP of 0.2 to 0.3 and are quite suitable for marine applications $[24,25]$.

The efficiency of cooling systems and chillers can be improved due to intensification of heat transfer in evaporators [26] and condensers [27], advanced scheme decisions [28, 29], deep utilization of exhaust heat [3032] with low temperature condensation [33, 34] to enhance the heat for conversion into refrigeration.

Various methods including ANSIS [35-37], statistical methods for processing monitoring data and ambient air parameters [38, 39] can be used for optimizing the thermal loads of ambient air cooling systems to match actual climatic conditions and provide

\footnotetext{
* Corresponding author: nirad50@gmail.com
} 
maximum effect gained [40-42]. The most of wellknown concepts of increasing the efficiency of trigeneration plant are limited to engine out-cycle use of refrigeration capacity and issue from conventional trigeneration with ACh $[17,18]$. A realization of incycle concept of EIAC would broaden the applicability of trigeneration even without enough cooling demands.

In order to stabilize engine intake air temperature a new concept of combined two-stage EIAC in ACh and ECh can be proposed [43, 44]. With this chilled water from $\mathrm{ACh}$ is used as a coolant in the high-temperature stage of engine inlet air cooler and boiling refrigerant of $\mathrm{ECh}$ - in the low-temperature stage.

The purpose of research is to estimate the enhancement of fuel efficiency of gas engine due to combined two-stage inlet air cooling on the base of monitoring data.

\section{Research methodology}

The efficiency of cooling air at the inlet of gas engine (GE) was investigated for trigeneration plant of "Sandora"-"PepsiCo Ukraine" (Nikolaev, Ukraine). It is equipped with two Jenbacher gas engine modules JMS 420 GS-N.LC (rated electric power $P_{\text {eISO }}=$ $1400 \mathrm{~kW}$ and heat $Q_{h}=1500 \mathrm{~kW}$ ) and ACh ARD500L2 Century.

The heath removed from GE is used for heating the water, used by $\mathrm{ACh}$ for producing a chilled water with temperature of about $12^{\circ} \mathrm{C}$. Chilled water is used for technological needs and by central conditioner for cooling engine room intake air, from where cooled air is sucked by engine turbochargers (Fig. 1).

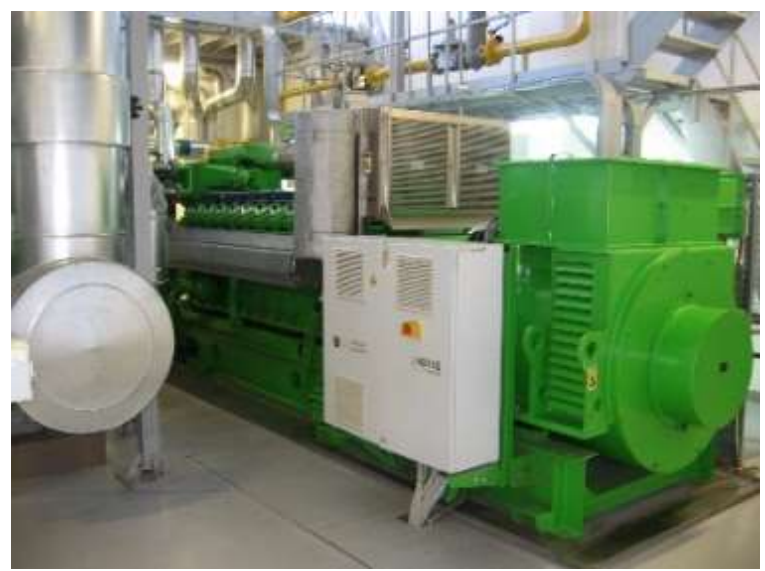

$a$

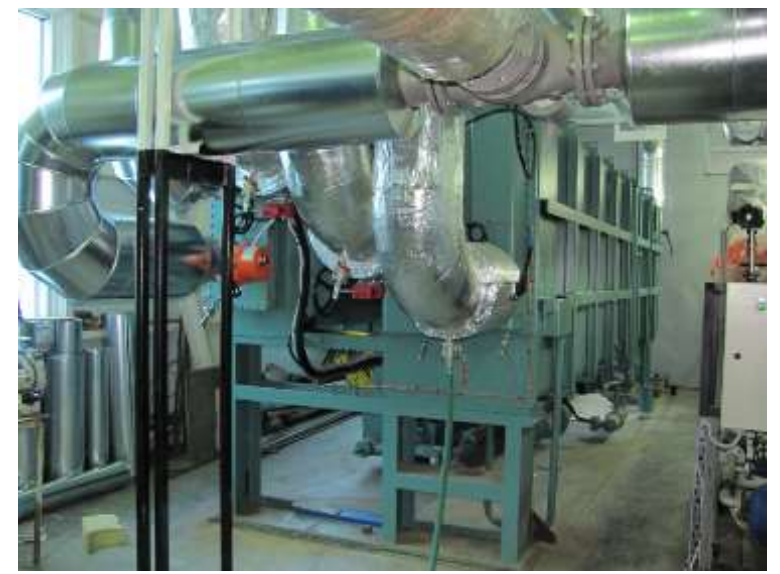

$b$

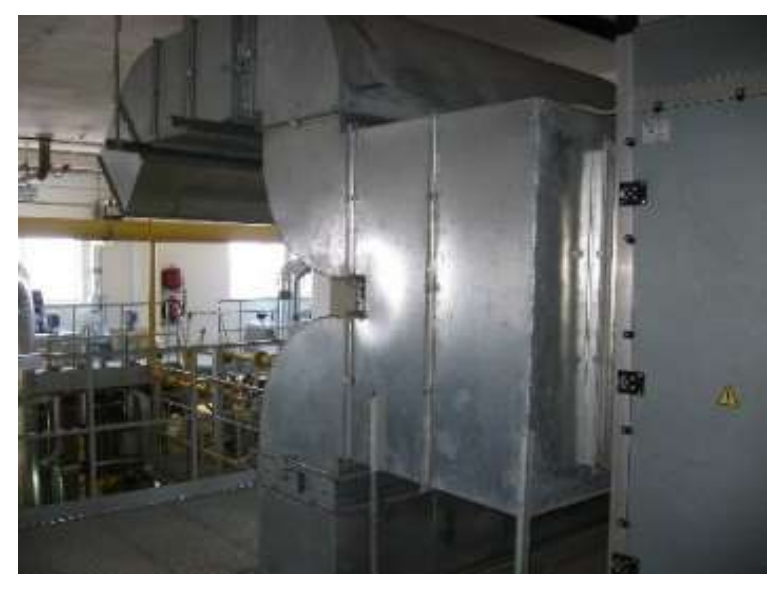

$c$

Fig.1. Cogeneration gas engine JMS GE Jenbacher (ם), absorption chiller AR-D500L2 Century (b) and central conditioner for cooling engine room intake air (c).

Such a conventional scheme of GE inlet air cooling system is presented in Fig. 2. Because of heat influx from the engine room environmental to cooled air flow the temperature of engine intake air $t_{\text {in }}$ is more higher than its value $t_{\mathrm{HT}}$ at the outlet of high-temperature air cooler $\mathrm{AC}_{\mathrm{HT}}: t_{\mathrm{in}}=t_{\mathrm{HT}}+\Delta t_{\mathrm{ER}}$, where $\Delta t_{\mathrm{ER}}-$ air temperature increment, caused by heat influx from the engine room (Fig.2,b). This proves a non-effective operation of conventional EIAC system (Fig.2, a).

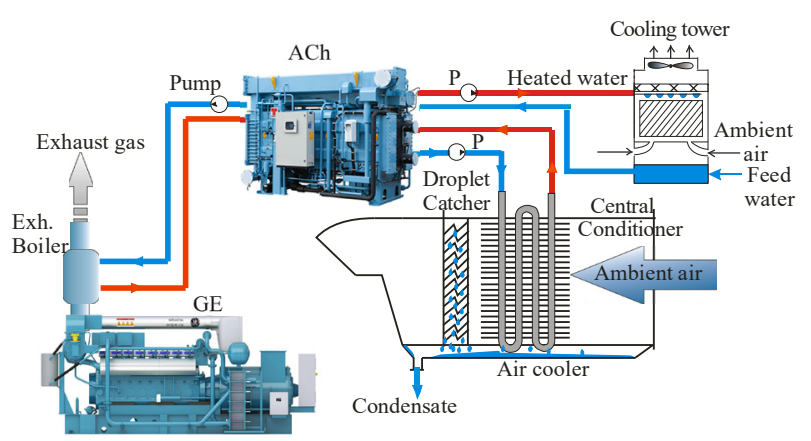




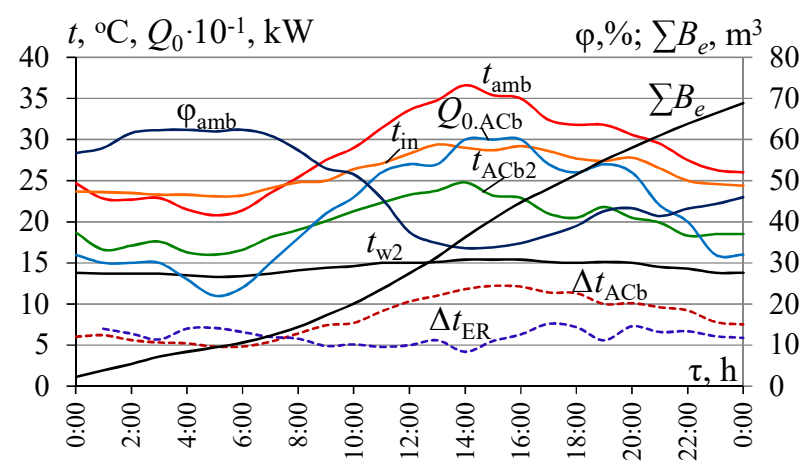

$b$

Fig. 2. A conventional system of gas engine inlet air cooling in the air cooler of the central conditioner by chilled water from ACh (a) and daily variation of temperature $t_{\mathrm{amb}}$ and relative humidity $\varphi_{\text {amb }}$ of ambient air, temperature of air at the inlet of gas engine turbocharger $t_{\text {in }}$, at the outlet of hightemperature air cooler $\mathrm{AC}_{\mathrm{HT}} t_{\mathrm{HT}}: \Delta t_{\mathrm{HT}}=t_{\mathrm{amb}}-t_{\mathrm{HT}}$; $\Delta t_{\mathrm{ER}}=t_{\text {in }}-t_{\mathrm{HT}}$.

In order to evaluate the effect of GE inlet air twostage cooling, compared with conventional conditioning all the ambient air coming into the engine room, the data of gas engine JMS 420 GS-N.L fuel efficiency monitoring were used.

The results of monitoring a gas engine fuel efficiency were presented in the form of data sets on dependence of fuel consumption $B_{\mathrm{e}}=f\left(t_{\mathrm{in}}\right)$, power output $P_{\mathrm{e}}=f\left(t_{\mathrm{in}}\right)$ and specific fuel consumption $b_{\mathrm{e}}=B_{\mathrm{f}} / P_{\mathrm{el}}$, as a result, upon the air temperatures $t_{\text {in }}$ at the inlet of the engine turbocharger. A method for processing the monitoring data on fuel consumption and power output of gas engine was developed [6-8].

The goal of processing the monitoring data sets $P_{\mathrm{e}}=$ $f\left(t_{\text {in }}\right), B_{\mathrm{e}}=f\left(t_{\text {in }}\right)$ and $b_{\mathrm{e}}=f\left(t_{\text {in }}\right)$ was to calculate the value of the change in specific fuel consumption $\Delta b_{\mathrm{e}}$ caused by the change in the engine inlet air temperature $t_{\text {in }}$ by $1{ }^{\circ} \mathrm{C}$, as $\Delta b_{\mathrm{e}} / \Delta t_{\text {in }}$, to evaluate the fuel saving effect due to application of advanced two-stage air cooling [6-8].

\section{Results}

The results of monitoring daily variation of volume gas consumption $B_{\mathrm{a}}$ and electric power output $P_{\mathrm{a}}$ of engine JMS 420 GS-N.LC are presented in Fig. 3-5.

$\mathrm{Be}, \mathrm{m}^{3} / \mathrm{h}$

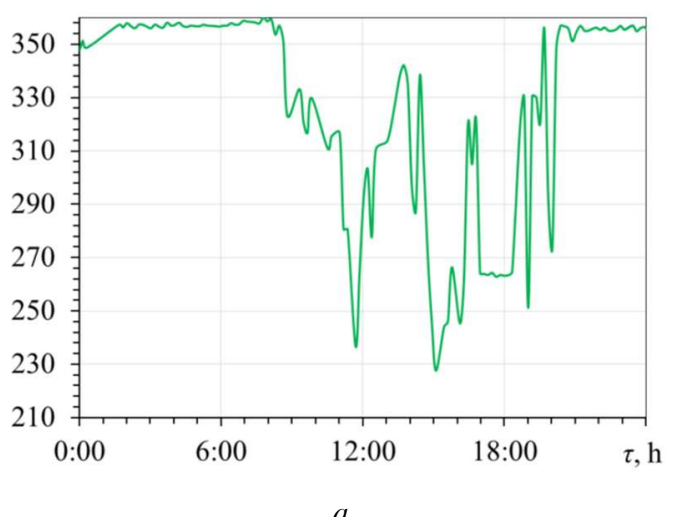

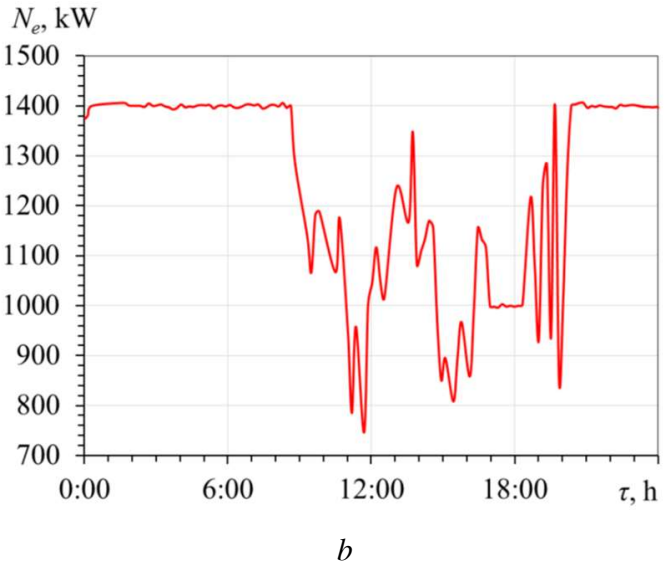

Fig.3. Daily variation of volume gas consumption $B_{e}(\mathbf{a})$ and electric power ouput $P_{e}(\mathbf{b})$ of gas engine with time $\tau$.

In summer hot day time interval $\tau=9 \ldots 20 \mathrm{~h}$ the ambient air temperatures are high: $t_{\mathrm{amb}}=30 \ldots 35^{\circ} \mathrm{C}$, that makes impossible reliable cooling the scavenge gas-air mixture by radiator to appropriate temperature level of about $40{ }^{\circ} \mathrm{C}$. This results in automatically reducing gas supply to engine followed by decreasing load (Fig.3).

A performance of gas engine in part load modes at arised intake air temperature $t_{\text {in }}(\tau=9 \ldots 20 \mathrm{~h})$ is followed by increase in specific gas consumption $b_{e}$ by $(20 \ldots 30) \cdot 10^{-3} \mathrm{~m}^{3} /(\mathrm{kW} \cdot \mathrm{h}) \quad$ (Fig. $\left.4, \mathrm{a}\right), \quad$ i.e. $\quad 8 \ldots 12 \%$ compared with engine full loading at ambient air temperatures $t_{\mathrm{amb}}$ and corresponding $t_{\mathrm{in}}$ lower then $25{ }^{\circ} \mathrm{C}(\tau=2 \ldots 9 \mathrm{~h})$.

As Fig. 4 shows, arising intake air temperature $t$ causes considerable increase in specific volume gas consumption $b_{e}$.

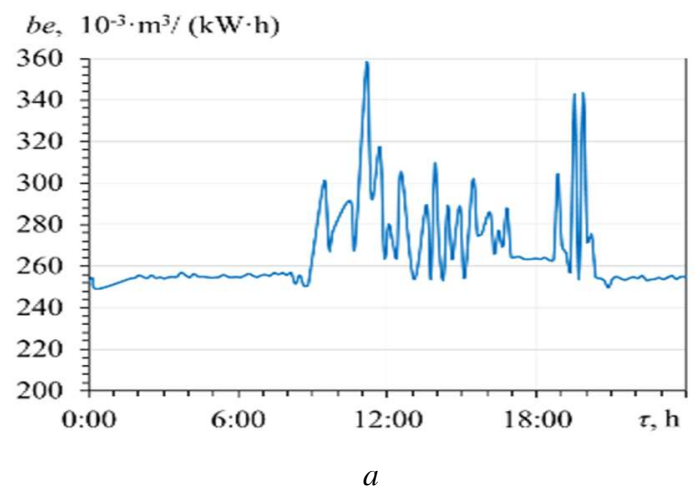

be, $10^{-3} \cdot \mathrm{m}^{3} /(\mathrm{kW} \cdot \mathrm{h})$

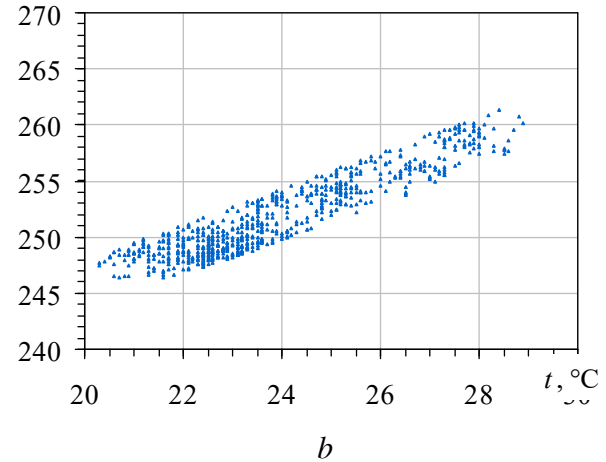

Fig. 4. Specific volume gas consumption $b_{a}$ variation with time during a day (a) and with intake air temperature $t$ (b). 
As Fig. 5 shows, with decreasing engine inlet air temperatures $t_{\text {in }}$ the mass specific fuel consumption $b_{\text {f }}$ reduses by 0.25 to $0.27 \mathrm{~g} /(\mathrm{kWh})$ for $1^{\circ} \mathrm{C}$ increment of engine inlet air temperature $\Delta t_{\text {in }}=1{ }^{\circ} \mathrm{C}$.
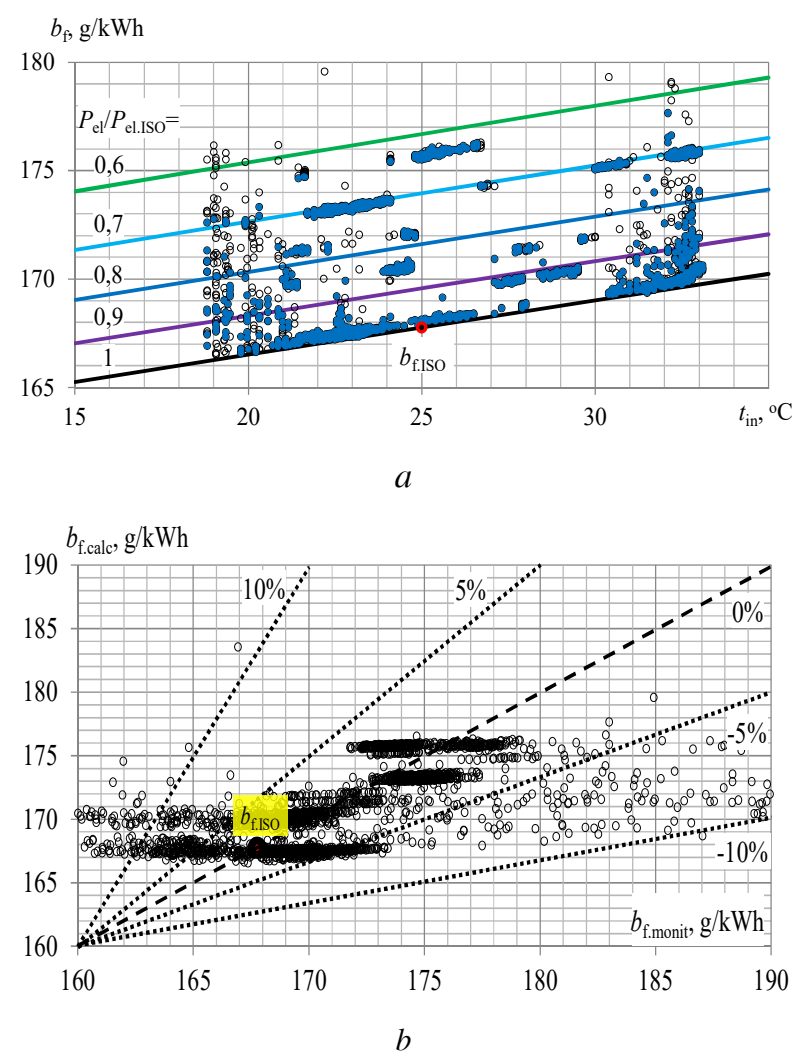

Fig. 5. Variation of mass specific fuel consumption $b_{\mathrm{f}}$ versus inlet air temperature $t_{\text {in }}$ at various loads $P_{\text {al }} / P_{\text {al.ISo }}=0.6 \ldots 1.0$ (a) and calculated values of mass specific fuel consumption $b$ f.calc compared with monitoring data $b_{\text {f.monit }}(\mathrm{b})$.

Proceeding from decrease in specific fuel consumption $b_{\mathrm{f}}$ with lowering engine inlet air temperatures $t_{\text {in }}$ a concept of addition subcooling intake air compared with its conventional cooling in ACh with chilled water temperature of about $12^{\circ} \mathrm{C}$, used for technological needs, is proposed (Fig. 6).

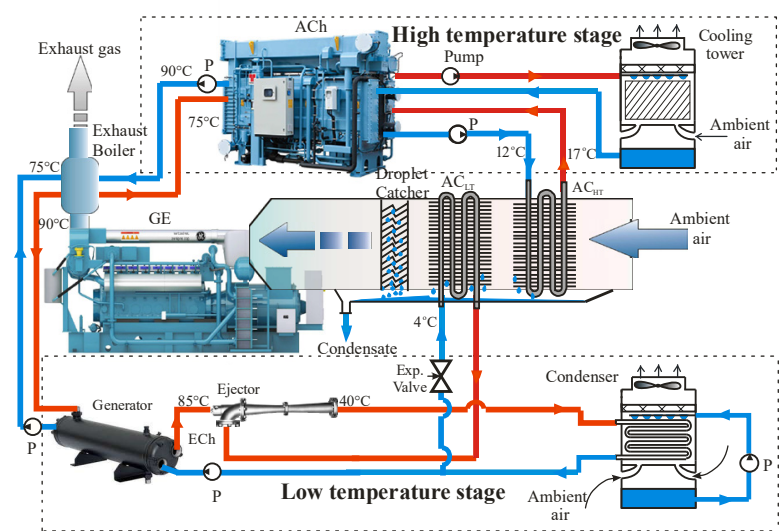

Fig. 6. The two-stage absorption-ejector (AECh) gas engine inlet air chilling system: АСнт - high-temperature air cooler; $\mathrm{AC}_{\mathrm{LT}}$ - low-temperature air cooler; $\mathrm{GE}$ - gas engine; $\mathrm{P}$ pump.

The results of calculation of heat loads $Q_{0 . \mathrm{HT}}$ - on the high-temperature stage $\mathrm{AC}_{\mathrm{HT}}$ and $Q_{0 . \mathrm{LT}}$ - on the lowtemperature stage $\mathrm{AC}_{\mathrm{LT}}$ and $Q_{0 . \mathrm{AC}}$ - on the developed two-stage air cooler based on measured air temperatures at the inlet of gas engine turbocharger $t_{\text {in }}$ effecting the engine fuel efficiency shows decreases in current specific fuel consumption $\boldsymbol{a} b_{\mathrm{e}}$ and daily summerised absolute volume gas saving $\mathbf{a} B_{\mathrm{e}}$ due to intake air cooling in high-temperature stage $\mathrm{AC}_{\mathrm{HT}}$ by $\mathrm{ACh}$ and low-temperature stage $\mathrm{AC}_{\mathrm{LT}}$ by $\mathrm{ECh}$ and the overall value for two-stage AECh (Fig. 7,b).

Thus, due to minimizing the heat influx from the engine room enviroments the proposed combined twostage air cooling system provides engine operation at practically stabilized low intake air temperatures at changeable climatic conditions. This leads to specific fuel consumption reduction by about $3-5 \mathrm{~g} /(\mathrm{kWh})$, i.e. about $3 \%$ decrease at increased ambient air temperatures $t_{\mathrm{amb}}$ (Fig. 7, a) and about 50\% increase in the annual fuel saving $\mathrm{B}_{\mathrm{f} .10}$ due to EIAC in AECh compared with its value $\mathrm{B}_{\mathrm{f} .15}$ due to EIAC in $\mathrm{AECh}$ (Fig. 7, b).
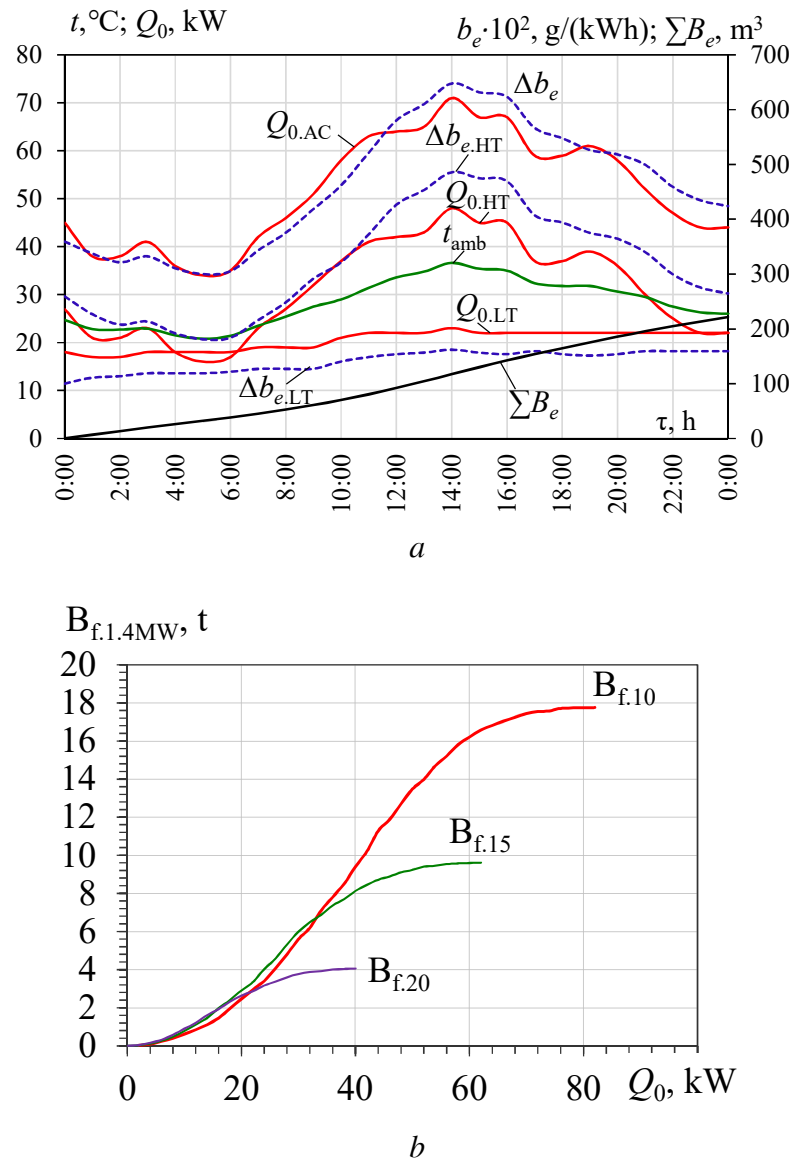

Fig. 7. Daily variation of heat loads $Q_{0 . \mathrm{HT}}$ on $\mathrm{AC}_{\mathrm{HT}}$ (ACh), $Q_{0 . \mathrm{LT}}$ on $\mathrm{AC}_{\mathrm{LT}}(\mathrm{ECh})$ and $Q_{0 . \mathrm{AC}}$ two-stage air cooler (AECh) and corresponding decreases in current specific fuel consumption $\Delta b_{\mathrm{e} . \mathrm{HT}}, \Delta b_{\mathrm{e} . \mathrm{LT}}, \Delta b_{\mathrm{e}}$ and summerised absolute volume gas saving $\Sigma B_{\mathrm{e}}$ (a) and annual fuel saving $\mathrm{B}_{\mathrm{f}}$ against installed cooling capacities $Q_{0}$ of chillers for engine inlet air temperatures: $t_{a 2}=15$ and $20^{\circ} \mathrm{C}$ in ACh; $t_{a 2}=10^{\circ} \mathrm{C}$ in AECh (Nikolayev, southen Ukraine, 2017).

\section{Conclusions}

A treatment of monitoring data sets on fuel efficiency of gas engine JMS 420 GS-N.L has proved inefficient conventional cooling the air entering engine room in 
ACh with chilled water temperature of $12{ }^{\circ} \mathrm{C}$, used for technological needs.

Proceeding from reducing the specific fuel consumption with lowering the engine intake air temperatures a novel concept of two-stage cooling air at the inlet of gas engines in trigeneration plants for food industries is proposed and corresponding engine intake air cooling (EIAC) system is developed. It includes ACh as the first high-temperature stage of EIAC and ECh as the second low-temperature stage.

The application of combined absorption-ejector chiller (AECh) provides stabilized operation of the engine in the rated mode with high fuel efficiency due to excluding heat influx to intake air flow from engine room environments.

The in-cycle trigeneration with combined two-stage waste heat recovery in the working cycle of the engine itself provides about $50 \%$ increase in the annual fuel saving for temperate climatic conditions as compared with conventional absorption EIAC and is very promising for food industries.

\section{References}

1. Cogeneration \& Trigeneration - How to produce energy efficiently. A practical guide for experts in emerging and developing economies. Zellner S., Burgtorf J., Kraft-Schäfer D. (eds.) Deutsche Gesellschaft für Internationale Zusammenarbeit (GIZ) GmbH, 144p. (2016)

2. K. Gluesenkamp, Y. Hwang, R. Radermacher, Applied Thermal Engineering 50, 6 p. (2013)

3. CIMAC position paper gas engine aftertreatment systems by CIMAC WG 17, Gas Engines, May 2017.

https://www.cimac.com/cms/upload/Publication_P ress/WG

Publications/CIMAC_WG17_2017_Aug_Position _Paper_Gas_Engine_Aftertreatment_Systems.pdf.

4. Jenbacher: http://www.

intma.ru/energetica/power_stations/thermal_ps_tri generation_ru.html.

5. S. Forduy, A. Radchenko, W. Kuczynski, A. Zubarev, D. Konovalov, Enhancing the fuel efficiency of gas engines in integrated energy system by chilling cyclic air, in Advanced Manufacturing Processes, InterPartner-2019, LNME, pp. 500-509 (2020)

6. A. Radchenko, D. Mikielewicz, S. Forduy, M. Radchenko, A. Zubarev, Monitoring the fuel efficiency of gas engine in integrated energy system, in Integrated Computer Technologies in Mechanical Engineering (ICTM 2019). AISC, 1113, pp. 361-370 (2020)

7. A. Radchenko, I-C. Scurtu, M. Radchenko, S. Forduy, A. Zubarev, Monitoring the efficiency of cooling air at the inlet of gas engine in integrated energy system, Thermal Science 2020 OnLineFirst Issue 00, 344-344 https://doi.org/10.2298/TSCI200711344R
8. A. Radchenko, E. Trushliakov, V. Tkachenko, B. Portnoi, O. Prjadko, Improvement of the refrigeration capacity utilizing for the ambient air conditioning system, in Advanced Manufacturing Processes II, InterPartner 2020, LNME, pp. 714723 (2021)

9. M. Radchenko, M. Radchenko, A. Radchenko, R. Radchenko, S. Kantor, D. Konovalov, V. Kornienko, Rational loads of turbine inlet air absorption-ejector cooling systems, Proceedings of the Institution of Mechanical Engineers, Part A: Journal of Power and Energy (2021). https://doi.org/10.1177/09576509211045455

10. R. Radchenko, N. Radchenko, A. Tsoy, S. Forduy, A. Zybarev, I. Kalinichenko, Utilizing the heat of gas module by an absorption lithium-bromide chiller with an ejector booster stage, in AIP Conference Proceedings, 2285, 030084 (2020)

11. E. Trushliakov, A. Radchenko, S. Forduy, A. Zubarev, A. Hrych, Increasing the operation efficiency of air conditioning system for integrated power plant on the base of its monitoring, in Integrated Computer Technologies in Mechanical Engineering (ICTM 2019), AISC, 1113, pp. 351$360(2020)$

12. A. Canova, C. Cavallero, F. Freschi, L. Giaccone, M. Repetto, M. Tartaglia, IEEE Industry Applications Magazine 15, 62 (2009)

13. J. Ortiga, J.C. Bruno, A. Coronas, Applied Thermal Engineering 50, 1536 (2013)

14. A. Radchenko, A Stachel, S. Forduy, B. Portnoi, O. Rizun, Analysis of the efficiency of engine inlet air chilling unit with cooling towers, in Advances in Design, Simulation and Manufacturing III (DSMIE 2020), LNME, pp. 322-331 (2020)

15. A. Radchenko, N. Radchenko, A. Tsoy, B. Portnoi, S. Kantor, Increasing the efficiency of gas turbine inlet air cooling in actual climatic conditions of Kazakhstan and Ukraine, in AIP Conference Proceedings 2285, 030071 (2020)

16. M. Radchenko, D. Mikielewicz, A. Andreev, S. Vanyeyev, O. Savenkov, Efficient ship engine cyclic air cooling by turboexpander chiller for tropical climatic conditions, in Integrated Computer Technologies in Mechanical Engineering (ICTM 2020), LNNS, 188, pp. 498507 (2021)

17. S.B. Kalhori, H. Rabiei, Z. Mansoori, Energy Conv. Manag. 60, 106 (2012)

18. J.L. Forsyth, Gas turbine inlet air chilling for $L N G$, in IGT International Liquefied Natural Gas Conference Proceedings 3, pp. 1763-1778 (2013)

19. D. Konovalov, H. Kobalava, M. Radchenko, I.-C. Scurtu, V. Sviridov, Determination of the evaporation chamber optimal length of a low-flow aerothermopressor for gas turbines, in Advanced Manufacturing Processes II, InterPartner 2020, LNME, pp. 654-663 (2021)

20. D. Konovalov, H. Kobalava, M. Radchenko, I.C. Scurtu, R. Radchenko, Determination of hydraulic 
resistance of the aerothermopressor for gas turbine cyclic air cooling, in TE-RE-RD 2020, E3S Web of Conferences, 180, 01012 (2020)

21. D. Konovalov, H. Kobalava, V. Maksymov, R. Radchenko, M Avdeev, Experimental research of the excessive water injection effect on resistances in the flow part of a low-flow aerothermopressor, in Advances in Design, Simulation and Manufacturing III (DSMIE 2020), LNME, pp. 292-301 (2020)

22. D. Butrymowicz, J. Gagan, K. Śmierciew, M. Łukaszuk, A. Dudar, A. Pawluczuk, A. Łapiński, , A. Kuryłowic, Investigations of prototype ejection refrigeration system driven by low grade heat, in HTRSE-2018, E3S Web of Conferences, 70, 7 p. (2018)

23. K. Smierciew, J. Gagan, D. Butrymowicz, J. Karwacki, Energy and Buildings 80, 260 (2014)

24. R. Radchenko, M. Pyrysunko, A. Radchenko, A. Andreev, V. Kornienko, Ship engine intake air cooling by ejector chiller using recirculation gas heat, in Advanced Manufacturing Processes. InterPartner-2020, LNME, pp. 734-743 (2021)

25. R. Radchenko, M. Pyrysunko, V. Kornienko, I.-C. Scurtu, R. Patyk, Improving the ecological and energy efficiency of internal combustion engines by ejector chiller using recirculation gas heat, In Integrated Computer Technologies in Mechanical Engineering (ICTM 2020), LNNS, 188, pp. 531541 (2021)

26. D. Mikielewicz, M. Klugmann, J. Wajs, International Journal of Thermal Sciences 65, 79 (2013)

27. T. Bohdal, W. Kuczynski, Heat Transf. Eng. 32, 359 (2011)

28. N.I. Radchenko, International Journal of Refrigeration 8(5), 267 (1985)

29. E. Trushliakov, M. Radchenko, T. Bohdal, R. Radchenko, S. Kantor, An innovative air conditioning system for changeable heat loads, in Advanced Manufacturing Processes, InterPartner2019, LNME, pp. 616-625 (2020)

30. V. Kornienko, M. Radchenko, R. Radchenko, D. Konovalov, A. Andreev, M. Pyrysunko, Improving the efficiency of heat recovery circuits of cogeneration plants with combustion of waterfuel emulsions. Thermal Science 25 (1 Part B), 791-800 (2021)

31. V. Kornienko, R. Radchenko, D. Konovalov, A. Andreev, M. Pyrysunko, Characteristics of the rotary cup atomizer used as afterburning installation in exhaust gas boiler flue, in Advances in Design, Simulation and Manufacturing III (DSMIE 2020), LNME, pp. 302-311 (2020)

32. V. Kornienko, R. Radchenko, D. Mikielewicz, M. Pyrysunko, A. Andreev, Improvement of characteristics of water-fuel rotary cup atomizer in a boiler, in Advanced Manufacturing Processes. InterPartner-2020, LNME, pp. 664-674 (2021)
33. V. Kornienko, R. Radchenko, Ł. Bohdal, L. Kukiełka, S. Legutko, Investigation of condensing heating surfaces with reduced corrosion of boilers with water-fuel emulsion combustion, in Integrated Computer Technologies in Mechanical Engineering (ICTM 2020), LNNS, 188, pp. 300309 (2021)

34. M. Radchenko, R. Radchenko, V. Kornienko, M. Pyrysunko, Semi-empirical correlations of pollution processes on the condensation surfaces of exhaust gas boilers with water-fuel emulsion combustion, in Advances in Design, Simulation and Manufacturing II (DSMIE 2019), LNME, pp. 853-862 (2020)

35. L. Bohdal, L. Kukielka, A.M. Radchenko, R. Patyk, M. Kułakowski, J. Chodór. Modelling of guillotining process of grain oriented silicon steel using FEM, in AIP Conference Proceeding 2078, 020080 (2019)

36. L. Bohdal, L. Kukielka, S. Świłło, A.M. Radchenko, A. Kułakowska, Modelling and experimental analysis of shear-slitting process of light metal alloys using FEM, SPH and visionbased methods, in AIP Conference Proceedings 2078, 020060 (2019)

37. L. Bohdal, L. Kukiełka, S. Legutko, R. Patyk, A.M. Radchenko, Materials 13, 3175 (2020)

38. M. Radchenko, R. Radchenko, V. Tkachenko, S. Kantor, E. Smolyanoy, Increasing the operation efficiency of railway air conditioning system on the base of its simulation along the route line, in Integrated Computer Technologies in Mechanical Engineering (ICTM 2019), AISC, 1113, pp. 461467 (2020)

39. E. Trushliakov, A. Radchenko, M. Radchenko, S. Kantor, O. Zielikov, The Efficiency of refrigeration capacity regulation in the ambient air conditioning system, in Advances in Design, Simulation and Manufacturing III (DSMIE 2020), LNME, pp. 343-353 (2020)

40. M. Radchenko, D. Mikielewicz, V. Tkachenko, M. Klugmann, A. Andreev, Enhancement of the operation efficiency of the transport air conditioning system, in Advances in Design, Simulation and Manufacturing III (DSMIE 2020), LNME, pp. 332-342 (2020)

41. N. Radchenko, E. Trushliakov, A. Radchenko, A. Tsoy, O. Shchesiuk, Methods to determine a design cooling capacity of ambient air conditioning systems in climatic conditions of Ukraine and Kazakhstan, in AIP Conference Proceedings, 2285, 030074 (2020)

42. N. Radchenko, A. Radchenko, A. Tsoy, D. Mikielewicz, S. Kantor, V. Tkachenko, Improving the efficiency of railway conditioners in actual climatic conditions of operation, in AIP Conference Proceedings, 2285, 030072 (2020)

43. R. Radchenko, M. Pyrysunko, V. Kornienko, D. Konovalov, O. Girzheva, Enhancing energy efficiency of ship diesel engine with gas ecological 
recirculation, in Advances in Design, Simulation and Manufacturing IV (DSMIE 2021), LNME, pp. 391-400 (2021)

44. A. Radchenko, E. Trushliakov, K. Kosowski, D. Mikielewicz, M. Radchenko, Energies 13, 6201 (2020) 